University of Rhode Island

DigitalCommons@URI

The Rhode Island Current Conditions Index

Economics

$1-2006$

\title{
Rhode Island Current Conditions Index - January 2006
}

Leonard Lardaro

University of Rhode Island, lardaro@uri.edu

Follow this and additional works at: https://digitalcommons.uri.edu/ricci

Part of the Econometrics Commons

Terms of Use

All rights reserved under copyright.

\section{Recommended Citation}

Lardaro, Leonard, "Rhode Island Current Conditions Index -- January 2006" (2006). The Rhode Island Current Conditions Index. Paper 82.

https://digitalcommons.uri.edu/ricci/82

This Article is brought to you for free and open access by the Economics at DigitalCommons@URI. It has been accepted for inclusion in The Rhode Island Current Conditions Index by an authorized administrator of DigitalCommons@URI.For more information, please contact digitalcommons-group@uri.edu. 


\section{GURRENT}

A new year, a new gear! Rhode Island began 2006 with a substantially better performance than it registered during most of 2005, finally moving beyond "first gear." For January, the Current Conditions Index rose from 58 to 67, with eight of its twelve indicators improving. More importantly, there were a number of very strong performers. Two of these (Single-Unit Permits and Retail Sales) registered astronomical increases, largely the result of seasonal effects associated with an atypically warm January. Of the remaining indicators that improved, all but one (Private Service Producing Employment) displayed strong changes.

First for the astronomical. In January, Single-Unit Permits, which measure new home construction, increased by 54.8 percent above its value last January. The number of Permits last January was atypically low, so the "comp" for this January's rise was easily exceeded. Retail Sales rose by just under 20 percent compared to a year ago. While weather was a factor here, the increasing importance of holiday gift cards, many of which were cashed in during January, played a

\begin{tabular}{lc}
\multicolumn{2}{c}{ CCI I ndicators - \% Change } \\
Government Employment & -0.3 \\
US Consumer Sentiment & -4.9 \\
Single-Unit Permits & 54.8 Y \\
Retail Sales & $19.8 \mathrm{Y}$ \\
Help Wanted Advertising & -1.0 \\
Priv. Serv-Prod Employment & $1.4 \mathrm{Y}$ \\
Total Manufacturing Hours & -3.4 \\
Manufacturing Wage & $2.0 \mathrm{Y}$ \\
Labor Force & $2.0 \mathbf{Y}$ \\
Benefit Exhaustions & $-5.7 \mathbf{Y}$ \\
New Claims & $-7.2 \mathbf{Y}$ \\
Unemployment Rate & $-6.0 \mathbf{Y}$ \\
\multicolumn{1}{|c}{ Y = I mproved Value } &
\end{tabular}

significant role. Retail Sales strength was especially strong in light of the fact that US Consumer Sentiment remained weak, falling by 4.9 percent compared to last January.

Benefit Exhaustions, which reflects long-term unemployment, and New Claims, a measure of layoffs, continued to perform well. Benefit Exhaustions fell by 5.7 percent, the seventh decline for this indicator in the last eight months. New Claims for Unemployment Insurance fell by 7.2 percent, the ninth consecutive month for which this indicator has improved. The recent strong performances by these two indicators is somewhat surprising, since labor demand, as measured by Help Wanted Advertising, has continued to weaken. For January, Help Wanted Advertising fell by one percent, matching its largest rate of decline since last October. This indicator has now fallen for three of the last four months. Continued declines in this indicator will make the recent gains in New Claims and Benefit Exhaustions difficult to sustain.

Our Labor Force continued to grow, rising by 2.0 percent in January. This relatively high growth rate is partly the result of a weak "comp" last January, as our Labor Force and Resident Employment fell through much of 2004 and remained weak during the first three months of 2005. The true test for Labor Force growth will begin in April, when the "comps" return to levels more typical of what we have witnessed in recent years. Our Unemployment Rate dropped from 5 percent last January to 4.7 percent this January. This is a positive result, especially as our Labor Force has been growing.

Government Employment fell in January (by $0.3 \%$ ), something we will see more of as budget tightening progresses. Along with this, Private Service-Producing Employment grew at a sluggish 1.4 percent rate. Ironically, this was actually a fairly typical growth rate for this indicator, based on the revised labor market data. Weakness in our goods-producing sector moderated, as the rate of decline in Total Manufacturing Hours slowed to 3.4 percent in January. As this was occurring, the Manufacturing Wage grew by 2.0 percent, its most rapid rate of increase since December of 2001.

Rhode Island began 2006 on a positive economic note. Expect more good news throughout the first half of 2006, after which the pace of economic activity here will begin to moderate, as the national economy slows and measures taken to balance our state's budget further reduce our rate of growth.

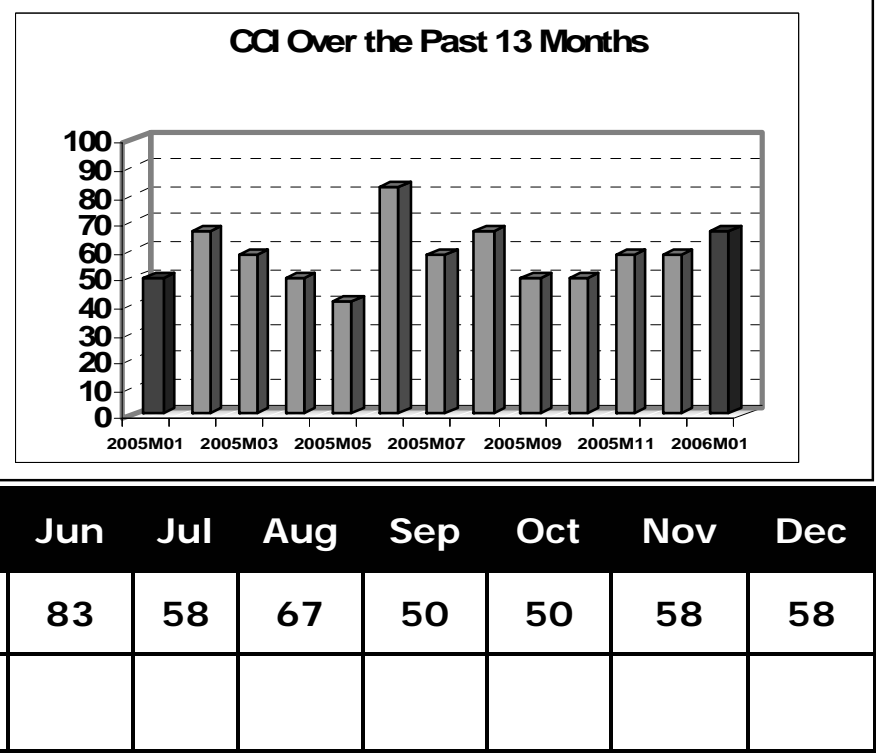

